Original Research Paper

\title{
Teachers' Information and Communication Technology Skills Assessment: Basis for a Comprehensive ICT Training Program
}

\author{
Shallimar A. Bayucca ${ }^{1}$ \\ ${ }^{1}$ Department of Education, Division of Meycauayan. Bulacan, Philippines.
}

Article History

Received:

11.10.2020

Revised:

05.11 .2020

Accepted:

19.11.2020

*Corresponding Author:

Shallimar A. Bayucca

Email:

shallimar.bayucca@deped. gov.ph

This is an open access article, licensed under: $\mathrm{CC}-\mathrm{BY}-\mathrm{SA}$

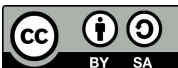

Abstract: The study described the extent of knowledge in ICT skills of 180 teachers as a basis for a training plan in a selected schools division in Region 3. A descriptive survey method was utilized having a weighted mean and standard deviation to treat the data collected. It was concluded that the teachers displayed a proficient extent of knowledge in basic ICT skills. However, some of the skills enumerated have a low mean and were close to the adjacent group scale of the lower level of knowledge. Furthermore, they showed limited knowledge in some advanced computer applications which are necessary for the construction of instructional materials. The selfassessment revealed that they are knowledgeable in ICT skills, but they do not know how to use it in complex applications. The skills for development based on the training needs assessment reiterated a combination of skills which further clarified that not all skills under a certain application are known. It is then recommended that training needs assessment should always be conducted by school administrators to gather data on the actual needs of the teachers as a basis in planning a thorough training matrix to ensure that the development and training provided are based on the needs of the teachers.

Keyword: ICT Training Needs, ICT Training Program, Information and Communication, Technology Skills. 


\section{Introduction}

We live in a world where technology and media-driven environment. Anyone can access any information, use rapidly changing technological tools, and can work together and make individual contributions on an unparalleled scale [1] (Framework for 21st-century learners). Effective citizens and workers must display a variety of functional and critical thinking skills. Information and Communication Technology or ICT literacy includes all skills necessary in the efficient performance of a job. ICT skills are part of the 21 st-century skills needed to succeed in the present generation.

With this fast advancement of technology, works are easier to manage. Being adaptable as they are, teachers are believed to comply with the demands of their work from teaching competence, pupildevelopment, community interaction, and professional growth by embracing these technologies and using it to complete works. The piling up loads of paper works in the field demands an easier way to meet deadlines.

However, some studies and literature state the different barriers in the implementation of ICT and most recommend that there is a need to train the teachers in ICT use to be able to provide the needed tools in the performance of their work.

In a study about ICT integration, the results of the study showed that a lack of technical support and assistance is one of the hindering factors that greatly affect the integration of ICT [2]. The difficulties in the use of ICT are related to the weakness of teacher's knowledge about what technologies are available and how they can be used in the educational process. They should know how to use ICT in relevant ways to help them in the delivery of the curriculum [3].

Another research paper suggested that teachers need to feel confident in their skills to assist student learning with technology and to incorporate technology into their classrooms. This can only happen when teachers undergo a more qualified development through a training workshop [4].

Previous research showed that teachers' professional development programs played a significant role in the effective integration of ICT in education [5]. The goal of these development programs and training was for teachers to acquire the necessary knowledge and skills to integrate ICT. Research also found out that traditional one-time teacher training (workshop, short training) program is not effective in assisting teachers to build technical competency for using ICT.

The result of the study of a group of investigators posited that the use of ICT tools in Uganda is evident but still recommended that teachers need training, so they may become regular users of ICT focusing on the acquisition of basic ICT skills [6]. The factors that positively influenced teachers and administrators' use of ICT in education include teachers' attitudes, ICT competence, computer selfefficiency, teaching experience, education level, professional level, professional development, accessibility, technical support, leadership support, and pressure of all factors increases the probability of excellent integration of ICT. Therefore, training of teachers on these pedagogical issues should increase and teachers must be convinced of the value of using ICT.

A researcher also emphasized that to embed ICT in the educational infrastructure, teacher training, curriculum structures and materials, classroom practices and models of assessment must be redesigned at all levels [7]. She further stated that in both schools and homes, Information and Communication technologies are widely seen as enhancing learning. This shows that a training program must be organized to provide a venue in equipping the teachers with the necessary skills.

However, integrating ICT is not that simple and easy as it seems. Lack of electricity, infrastructures, internet connection, equipment, initiative from school heads, and lack of teacher confidence were the hindrances encountered in the implementation of ICT. The lack of technical experience of the teachers and staff complicates the problem of integration. Based on a survey on a high school test performance, almost half of the respondents remained to be ICT-illiterate [8]. This means that the teachers are not able to use technology in their teaching. They also found out that lack of enough technical support for operating and maintaining ICT resources and the lack of teacher training opportunities are considered barriers to change. In relation, another study stated that few school directors, staff, and teachers are trained in using basic ICT tools such as Excel or Edusoft and in applying them to assessing student performance in schools and classrooms [9]. Teachers cannot force students to develop higher-order thinking skills without having acquired such skills themselves. ICT use is dependent on a teacher's skills.

While teachers are indeed using various ICTs in their teaching, they are incapacitated by inadequate training and lack of continuous professional development [10]. Their research also identified barriers that are working against full ICT integration in the teacher education curriculum 
and these include access to ICT resources, technical problems associated with ICT use such as poor internet connectivity, and lack of training programs.

Teacher training on ICT utilization has emerged as an important issue in higher education in Mainland China [11]. Other researchers focused on the said problem and have put forward a worthy outcome and consideration to solve this problem. There are two options considered in improving the performance of teachers in ICT utilization - The training Content and Training Model. The Training Content must focus on the restructuring of the existing curriculum and contents to fit the ICT training needs of teachers since there has been a drastic change in technology over the years. The Training Model sees through the educational technology competence of higher education faculty and investigates models and approaches of professional development. This considers teacher training as an effective means of enhancing teachers' technological skills in all aspects including design, development, utilization, management, and evaluation of teacher resources, and the optimization of acquiring the skills.

Training for teachers' capability on ICT should adapt the current trend in technology and training programs should be implemented through the Learning Management System. Different from a regular training program focused on training contents, ICT training should pay more attention to the blended training model. This model refers to face-to-face training and hands-on training. A blended training model that considers the differences and provides a variety of mediums from which teachers are more likely to find something that suits their teaching and learning style.

Planning training programs should be based on research to determine the training needs of the expected training participants. This can only be done through a training needs assessment.

However, conducting a training needs assessment is a challenging and complicating task, especially when this is the first step for developing an innovative training service [12]. The training needs assessment process provides valuable input to the design process of the program and the development of the appropriate content. The results of the assessment reflect the convergence that has been detected between the user in technology areas of common interest and common gaps in skills and competencies that affect the performance.

The integration of ICT in teacher training programs focuses on incorporating essential subject content and knowledge from their disciplines and requires more hands-on practice [13]. Extensive and continuous training is essential for the incorporation of ICT and pedagogy together. The author also found out that the few teachers in Bangladesh who have technical mastery in using ICT still do not have sufficient competency to incorporate ICT and pedagogy.

When teachers are hesitant to integrate ICT in all phases of the curriculum, the use of ICT at school will not be successful [14]. Teachers' reluctance in using ICT is due to their low confidence in their ICT knowledge and skills. Authors also shared that the Government of Indonesia through the Ministry of Education and Culture (MoEC) is continuously implementing various efforts to enhance the professionalism of teachers by providing ICT training for teachers. However, most training present challenges for teachers to participate including geographical challenges such as cost for traveling and accommodation, limited opportunities for training where teachers must take leave to attend training, available equipment, difficult to suit teachers and instructor's time, and requisites of computer and internet connection where only teachers who have computer/laptops and an internet connection can participate.

On a background paper, it showed that poor or improper usage and management of ICT may result in underperformance in educational outcomes [15]. The ineffective use of ICT-assisted instruction wastes which can be used in other more important learning matters. Effective usage requires quality teacher training. More specifically, effective teacher training and appropriate linkage to ICT usage, which give rise to sound pedagogy have different acquisition approaches based on different types of learning. This framework can be adapted in the formulation of the comprehensive training program.

Teacher training needs are closely linked with technological competencies, suggesting that teachers believe they must master technological resources before using them [16]. In a study, information, media, and technology skills of respondents were found very satisfactory from a higher education institution $[17,18]$. Teachers also need to learn and adopt new technologies, and a study showed a very good evaluation in this part of the survey [19].

This study intends to analyze the ICT skills of teachers in some selected schools located in Region 3, Philippines. Also, the result of the study intends to become a basis for a comprehensive ICT training program. 


\section{Methodology}

\subsection{Research Design}

In this particular study, the researcher used a descriptive type of research. A survey on hand was used as a primary data gathering tool for the study. In the survey, the different ICT Skills were enumerated for the respondents to determine their levels.

This study aims to describe certain phenomena or characteristics of a population. Descriptive research generally precedes explanatory research. Descriptive research also studies the relationships of variables [20]. Thus, this method was used in the study as it described the skills of the respondents when it comes to the use of information and communication technology.

\subsection{Respondents}

The respondents of the study were 180 public elementary teachers in Cluster A of the City Schools Division of Meycauayan chosen by purposive sampling technique.

\subsection{Instrument of the Study}

The researcher used a self-devised questionnaire. The questionnaire contained different ICT skills: Microsoft Office Word, Microsoft Office Excel, Microsoft Office PowerPoint, Microsoft Office Publisher, Google Apps, and other applications. The contents were subjected for validity from a panel of experts which includes a research adviser, an independent researcher, a college professor, a head teacher and an administrator. Their comments and suggestions were considered in improving the instrument.

\subsection{Statistical Analysis}

To analyze the teachers' information and communication technology (ICT) skills, the study used weighted mean and standard deviation as statistical tools. The tools mentioned were used to describe the group scores concerning the ICT skills and training needs of the respondents with the following scale score and description indicated in Table 1.

Table 1. Group Scores Concerning the ICT Skills and Training

\begin{tabular}{ccl}
\hline SCALE SCORE & \multicolumn{1}{c}{ DESCRIPTION } \\
\hline 4 & $3.51-4.00$ & $\begin{array}{l}\text { Highly Proficient (HP)-Teacher performance in the ICT skills } \\
\text { consistently exceeds expectations. The teacher is well-versed } \\
\text { on the know-how of the skill }\end{array}$ \\
\hline 3 & $2.51-3.50$ & $\begin{array}{l}\text { Proficient (P) - Teacher performance in the ICT skills } \\
\text { somewhat meets the expectations. The teacher is somewhat } \\
\text { knowledgeable in the skill. }\end{array}$ \\
\hline 2 & $1.51-2.50$ & $\begin{array}{l}\text { Basic (B) - Teacher performance in the ICT skills meet basic } \\
\text { expectations. Teacher's knowledge in the skill is limited }\end{array}$ \\
\hline 1 & $1.00-1.50$ & Below Basic (BB) - Teacher does not know the ICT skill \\
\hline
\end{tabular}

\section{Results and Discussion}

The study intends to assess and analyze the information and communication technology skills of teachers from selected schools located in Region 3, Philippines. The succeeding tables presented the weighted mean and standard deviation of the extent of knowledge of teachers in Information and Communication Technology skills with their corresponding interpretation.

Table 2 shows skill 10, inserting header/footer/page number, has the lowest mean of 3.02 but is still under proficient rating. While skill 1, starting/shutting down the computer, has the highest computed mean of 3.68 which falls under highly proficient. It also presents an average weighted mean of 3.38 which indicates a proficient extent of knowledge in basic computer commands. It further portrays that four skills under basic commands were rated highly proficient which indicates that the teachers are well-versed on the know-how of the said skill and that they use these skills every day. Six skills that were rated proficient in the teachers' performance in the ICT skills somewhat met the expectations of having teachers who are knowledgeable of the skills. In a study, when teachers are 
hesitant to integrate ICT in all phases of the curriculum, the use of ICT at school will not be successful [14]. In a similar study, the researchers also mentioned that regardless of numerous ICT training programs directed for teachers, the result from an online National Examination of Teachers' Competency was still low.

Table 2. The extent of Knowledge of Teachers in Basic Computer Commands

\begin{tabular}{llccc}
\hline & \multicolumn{1}{c}{ Skill } & Mean & SD & Interpretation \\
\hline 1 & starting/shutting down the computer & 3.68 & 0.70 & Highly Proficient \\
\hline 2 & encoding data & 3.50 & 0.83 & Highly Proficient \\
\hline 3 & printing single documents & 3.55 & 0.78 & Highly Proficient \\
\hline 4 & printing tiled documents & 3.25 & 1.00 & Proficient \\
\hline 5 & setting-up margins/orientation/paper size/column & 3.22 & 0.94 & Proficient \\
\hline 6 & saving document manually and using shortcut keys & 3.30 & 0.88 & Proficient \\
\hline 7 & copy, move and paste text/picture/document & 3.52 & 0.84 & Highly Proficient \\
\hline 8 & recovering text by using redo/undo icons & 3.33 & 1.00 & Proficient \\
\hline 9 & formatting text (bold, italic, underline, etc.) & 3.45 & 0.89 & Proficient \\
\hline 10 & inserting header/footer page number & 3.02 & 1.07 & Proficient \\
\hline & Average Weighted Mean & $\mathbf{3 . 3 8}$ & $\mathbf{0 . 8 9}$ & PROFICIENT \\
\hline
\end{tabular}

Table 3 presents the highest computed mean of 3.18 (changing font size/font style of text) falls in the proficient level while using watermarks/page color/page borders got the lowest mean of 2.43 which is interpreted under the basic level of knowledge. It further shows that the extent of knowledge in Microsoft Word of the teachers has a weighted average mean of 2.94 that connotes a proficient level of knowledge. While the teachers' extent of knowledge is proficient which means somewhat knowledgeable as to the use of basic Microsoft Word applications, they showed weakness in the advanced application which is inserting watermark/page border/page color. But according to a related study, it stated that the use of ICT usually faces certain obstacles [21]. Teachers need to be equipped with technology-related management skills aside from basic skills.

Table 3. The extent of Knowledge of Teachers in Microsoft Word

\begin{tabular}{llccc}
\hline & \multicolumn{1}{c}{ Skill } & Mean & SD & Interpretation \\
\hline 1 & changing font size/font style of text & 3.18 & 0.93 & Proficient \\
\hline 2 & inserting images/tables/charts/word arts & 3.08 & 0.85 & Proficient \\
\hline 3 & inserting bullets/numbers & 3.01 & 0.86 & Proficient \\
\hline 4 & using watermarks/page color/page borders & 2.43 & 0.71 & Basic \\
\hline 5 & aligning text (align left, center, align right) & 3.02 & 0.87 & Proficient \\
\hline & Average Weighted Mean & $\mathbf{2 . 9 4}$ & $\mathbf{0 . 8 4}$ & PROFICIENT \\
\hline
\end{tabular}

Table 4 reveals that the teachers' extent of knowledge on the use of Microsoft Excel is proficient as seen from the weighted average of 3.03. However, computing using a formula has received a basic rating. Microsoft Excel is mostly used in the preparation of different school forms and class records. It is also used in other related reports of numbers. Receiving a basic rating, computing using a formula showed that the teachers do not know how to input a formula in a spreadsheet to make their computation easier which further shows that they still compute numbers manually except in forms where formula was already encoded. From an inaugural lecture, it was stated that few school directors, staff, and teachers are trained in using basic ICT tools such as Excel or Edusoft and in applying them to assessing student performance in schools and classrooms and that teachers cannot develop higher-order thinking skills in students without having acquired such skills themselves [9]. The use of ICT is dependent on the skills of the teachers. 
Table 4. The extent of Knowledge of Teachers in Microsoft Excel

\begin{tabular}{clccc}
\hline & \multicolumn{1}{c}{ Skill } & Mean & SD & Interpretation \\
\hline 1 & merging/splitting cells & 2.95 & 0.99 & Proficient \\
\hline 2 & inserting images & 3.17 & 0.95 & Proficient \\
\hline 3 & formatting cells (borders) & 2.95 & 0.95 & Proficient \\
\hline 4 & filling a series of number & 3.02 & 0.97 & Proficient \\
\hline 5 & computing using a formula & 2.43 & 1.06 & Basic \\
\hline 6 & sorting alphabetically/ascending/descending & 3.04 & 1.00 & Proficient \\
\hline 7 & inserting and deleting columns/rows & 3.20 & 0.97 & Proficient \\
\hline 8 & adding another worksheet/spreadsheet & 3.08 & 1.03 & Proficient \\
\hline 9 & renaming sheets & 3.14 & 1.03 & Proficient \\
\hline 10 & adjusting the width and height of cells & 3.28 & 0.93 & Proficient \\
\hline \multicolumn{2}{r}{ Average Weighted Mean } & $\mathbf{3 . 0 3}$ & $\mathbf{0 . 9 9}$ & PROFICIENT \\
\hline
\end{tabular}

Table 5. The extent of Knowledge of Teachers in Microsoft PowerPoint

\begin{tabular}{llccc}
\hline & Skill & Mean & SD & Interpretation \\
\hline 1 & opening a new document & 3.49 & 0.91 & Proficient \\
\hline 2 & inserting a new slide & 3.38 & 0.90 & Proficient \\
\hline 3 & formatting background & 3.12 & 1.06 & Proficient \\
\hline 4 & inserting background & 3.12 & 1.05 & Proficient \\
\hline 5 & inserting images/shapes/tables/charts & 3.14 & 1.11 & Proficient \\
\hline 6 & formatting images/shapes/tables/charts & 3.00 & 1.08 & Proficient \\
\hline 7 & designing the slides & 3.15 & 1.08 & Proficient \\
\hline 8 & applying animations & 3.08 & 1.04 & Proficient \\
\hline 9 & applying hyperlinks & 2.45 & 0.85 & Basic \\
\hline 10 & producing learning software (SIM, SLK) & 2.38 & 0.92 & Basic \\
\hline \multicolumn{1}{c}{ Average Weighted Mean } & $\mathbf{3 . 0 3}$ & $\mathbf{1 . 0 0}$ & PROFICIENT \\
\hline & & & &
\end{tabular}

Table 5 shows a 3.03 average weighted mean which means a proficient knowledge of teachers in Microsoft PowerPoint. The results revealed that the respondents are already familiar with simple slide presentation since it is used every day in the conduct of the teaching-learning process. However, when it comes to complex slide presentations such as Self-Learning Kits and Strategic Intervention Materials that use hyperlinks in their construction, the knowledge of teachers is at the basic level. These suggest that the teachers need further training with the use of hyperlinks to be able to come up with their instructional material that fits their learners. In a separate context, a study found that in terms of faculty development, the office/ department encourages continual learning and development $[22,23]$.

Table 6. The extent of Knowledge of Teachers in Microsoft Publisher

\begin{tabular}{llccc}
\hline & \multicolumn{1}{c}{ Skill } & Mean & SD & Interpretation \\
\hline 1 & creating a blank page & 2.96 & 1.12 & Proficient \\
\hline 2 & inserting images/textbox/word art & 2.94 & 1.13 & Proficient \\
\hline 3 & inserting picture holder & 2.69 & 0.99 & Proficient \\
\hline 4 & changing templates & 2.69 & 1.03 & Proficient \\
\hline 5 & choosing a publication page & 2.68 & 1.01 & Proficient \\
\hline 6 & formatting publication & 2.58 & 1.00 & Proficient \\
\hline \multicolumn{2}{c}{ Average Weighted Mean } & $\mathbf{2 . 7 5}$ & $\mathbf{1 . 0 5}$ & PROFICIENT \\
\hline
\end{tabular}


Table 6 presents a proficient extent of knowledge of teachers in Microsoft Publisher with an average weighted mean of 2.75. Skill 1(creating a blank page) has the highest mean of 2.96 while skill 6 (formatting publication) has the lowest mean of 2.58. While the computed means are under a proficient level, they are not far from the maximum score for the basic level of proficiency which is 2.50. These suggest that they are knowledgeable in the basic skills under Microsoft Publisher but without regular utilization, it will eventually fall under the basic level. The integration of ICT requires more hands-on practice. Teachers' technical abilities in using ICT is the first issue to consider [13]. The investigator also found out that few teachers who have technical mastery in using ICT still do not have enough competency to incorporate ICT.

Table 7. The extent of Knowledge of Teachers in Google Apps

\begin{tabular}{llccc}
\hline & \multicolumn{1}{c}{ Skill } & Mean & SD & Interpretation \\
\hline 1 & internet browsing & 3.58 & 0.77 & $\begin{array}{c}\text { Highly } \\
\text { Proficient }\end{array}$ \\
\hline 2 & using email (reading and sending mails) & 3.27 & 0.90 & Proficient \\
\hline 3 & downloading and saving files from the internet & 3.48 & 0.86 & Proficient \\
\hline 4 & $\begin{array}{l}\text { using chat rooms and forums (Facebook, Twitter, } \\
\text { Instagram) }\end{array}$ & 3.35 & 0.84 & Proficient \\
\hline 5 & publishing a personal blog & 2.37 & 0.98 & Basic \\
\hline 6 & designing a web page or personal site & 2.42 & 1.09 & Basic \\
\hline 7 & google-sheets & 2.48 & 1.01 & Basic \\
\hline 8 & google drive & 2.50 & 0.95 & Basic \\
\hline 9 & $\begin{array}{l}\text { google scholar (research articles, journals, } \\
\text { publications) }\end{array}$ & 2.42 & 1.00 & Basic \\
\hline & $\quad$ Average Weighted Mean & $\mathbf{2 . 8 7}$ & $\mathbf{0 . 9 3}$ & PROFICIENT \\
\hline
\end{tabular}

Table 7 shows varied interpretations of highly proficient, proficient, and a basic level of knowledge. However, the average weighted mean was interpreted under the proficient rating scale. Internet browsing has a computed mean of 3.58 which means that the teachers are highly proficient in using the skill. This shows that the teachers' competence in this skill exceeds expectations. The four skills under the proficient extent of knowledge are the ones mostly used in the performance of their task. This shows that the teacher's performance in the ICT skills somewhat meets the expectations and that they are somewhat knowledgeable in the skill. Having a mean of $1.50-2.50$, five skills were categorized under the basic extent of knowledge. This further revealed that there are skills under a certain application that the teachers have limited knowledge and so they cannot use it properly. A group of researchers suggested that teachers believe they must master technological resources before using them [16]. They further concluded that training plans must be arranged at different levels and stages. This allows the teachers to select specific skills that need improvement according to their level of self-assessment.

Table 8. The extent of Knowledge of Teachers in Other Computer Applications

\begin{tabular}{llccc}
\hline & Skill & Mean & SD & Interpretation \\
\hline 1 & adobe photoshop & 2.10 & 1.00 & Basic \\
\hline 2 & power director & 2.10 & 1.04 & Basic \\
\hline 3 & movie maker & 2.19 & 1.06 & Basic \\
\hline 4 & windows media & 2.20 & 1.06 & Basic \\
\hline 5 & acrobat reader & 2.14 & 1.02 & Basic \\
\hline \multirow{2}{*}{6} & $\begin{array}{l}\text { searching for saved data in USB or other storage } \\
\text { devices }\end{array}$ & 3.34 & 0.84 & Proficient \\
\hline 7 & setting-up/using a projector & 2.92 & 1.02 & Proficient \\
\hline & Average Weighted Mean & $\mathbf{2 . 3 9}$ & $\mathbf{1 . 0 5}$ & BASIC \\
\hline
\end{tabular}


Table 8 displays an average weighted mean of 2.39 which was interpreted as basic about the extent of knowledge of the teachers in other computer applications. This further shows that the teachers' knowledge of the skills is limited. The enumerated applications where the teachers have basic knowledge are advanced computer applications. Some of these skills are needed to produce videos that can be used in the teaching-learning process.

\section{Conclusions}

Based on the results of the study, the researcher, therefore, concluded that the teachers displayed a proficient extent of knowledge in basic computer commands, word processor, spreadsheet, slide presentation, and publisher. However, some of the skills enumerated in each group have a low mean and were close to the adjacent group scale of the lower level of knowledge. Furthermore, they showed limited knowledge in some google apps and other advanced computer applications which are also necessary for the construction of instructional materials. While the teachers' self-assessment showed that they are proficient in the basic skills enumerated under Microsoft Word, Excel, PowerPoint, and Publisher, the result of the training needs assessment revealed that they still need training/workshops on the application of such skills. It also revealed that they are knowledgeable about the skills but are not confident about how to use it. A comprehensive training program was crafted based on the assessment which focused on the skills where the teachers assessed themselves as with below basic and basic extent of knowledge.

\section{Recommendations}

Based on the results and conclusion of the study, the researcher hereby recommends the following:

(1) School Administrators must provide the teachers the opportunities to update themselves on the use of technology for them to be adept with the demands of their work.

(2) School Administrators should ensure that the development and training provided are based on the needs of the teachers.

(3) A training needs assessment should always be conducted to be able to gather data on the actual needs of the teachers as a basis in crafting a training matrix.

\section{References}

[1] Partnership for $21^{\text {st }}$ Century Learning, "Framework for $21^{\text {st }}$-Century Learning," 2016. Available: http://static.battelleforkids.org/documents/p21/P21_framework_0816_2pgs.pdf [Accessed: 2019]

[2] M. Kelentric, "Integration of ICT into Initial Education of Classroom Teachers: The Cases of Two Regions in Croatia," Unpublished Master's Thesis, University of Oslo, 2013.

[3] D. Morris, "Are teacher's technophobes? Investigating Professional Competency In The Use Of ICT to Support Teaching And Learning," Procedia-Social and Behavioral Sciences, vol. 2, no. 2, pp. 4010-4015. doi: 10.1016/j.sbspro.2010.03.632, 2010.

[4] L. Ward, and J. M. Parr, "Revisiting and Reframing Use: Implications for Integration of ICT," Computers \& Education, vol. 54, no. 1, pp. 113-122, 2010. doi: 10.1016/j.compedu.2009. 07.011 .

[5] K. F. Hew, and T. Brush, "Integrating Technology into K-12 Teaching and Learning: Current Knowledge Gaps and Recommendations for Future Research," Educational Technology Research and Development, vol. 55, no. 3, pp. 223-252, 2007. doi: 10.1007/s11423-006-90225.

[6] G. Ali, F. A. Haolader, and K. Muhammad, "The role of ICT to Make Teaching-Learning Effective in Higher Institutions of Learning in Uganda," International Journal of Innovative Research in Science, Engineering and Technology, vol. 2, no. 8, pp. 4061-4673, 2013.

[7] S. Livingstone, "Critical Reflections on the Benefits of ICT In Education," Oxford Review of Education, vol. 38, no. 1, pp. 9-24, 2011. doi: 10.1080/03054985.2011.577938.

[8] Jr. J. Camacho, and R. M. Pintor, "An Analysis of the Effect of ICT Integration in High School Test Performance in Masbate, Philippines," Osaka University Knowledge Archive, vol. 15, no. 2, pp. 19-34, 2011.

[9] M. Carnoy, "ICT in Education: Possibilities and Challenges," 2003. [Online], Available: https://www.uoc. edu/inaugural04/eng/carnoy1004.pdf. [Accessed: 2019] 
[10] M. Ziweya, and C. Musarurwa, "Training Needs Assessment and Utilization of Information and Communication Technology in Secondary Teacher Education Colleges in Zimbabwe," Asian Journal of Management Science \& Education, 3(2), pp. 80-88, 2014.

[11] A. Qiao, and N. Wang, "An investigation of Teachers' Needs on Using ICT in Teaching and Learning," International Conference on Computer Engineering and Applications, vol. 2, pp. 285-289, 2011.

[12] P. Zaharias, and A. Poulymenakou, "Identifying Training Needs for ICT Skills Enhancement in South-Eastern Europe: Implications for Designing Web-Based Training Courses," Educational Technology \& Society, vol. 6, no. 1, pp. 50-54, 2003.

[13] S. Khan, "A model for Integrating ICT Into Teacher Training Programs in Bangladesh Based on TPCK (Technology Pedagogy Content Knowledge)," International Journal of Education and Development using Information and Technology, vol. 10, no. 3, pp. 21-31, 2014.

[14] I. K. Yusri, and R. Goodwin, "Mobile learning for ICT training: Enhancing ICT skills of teachers in Indonesia," International Journal of e-Education, e-business, e-Management, and elearning, vol. 3, no. 4, pp. 293-296, 2013.

[15] J. Toit, "Teacher training and Usage of ICT in Education. UNESCO Institute for Statistics," [Online]. Available: https://studylib.net/doc/18436011/teacher-training-and-usage-of-ict-ineducation-new. [Accessed: 2019].

[16] G. Almerich, J. J. Suarez-Rodriguez, C. Blloch, and R. M. Bo, "Training needs of teachers in ICT: Training profiles and elements of complexit," Revista Electronica de Investigacion y Evaluacion Educativa, vol. 17, no.2, 2011. doi: 10.7203/relieve.17.2.4006

[17] J. M. R. Asio, and E. E. Riego de Dios, “The College Students' Perspective On What Makes An Educator Well-Qualified", Journal of Pedagogical Research, vol. 3, no. 3, pp. 126-138, 2015.

[18] J. M. R. Asio and E. E. Riego de Dios, " $21^{\text {st }}$-century attributes and skills of a teacher in the perspective of college students," Online Submission, 2019, doi: 10.13140/RG.2.2.12410. 75204.

[19] J. M. R. Asio, E. E. Riego de Dios, and A. M. E. Lapuz, "Professional Skills and Work Ethics of Selected Faculty in A Local College", PAFTE Research Journal, vol. 9, no. 1, pp. 164-180, 2019.

[20] F. M. Zuluetaand, and J. R. N, Costales Methods of Research Thesis-Writing and Applied Statistics. Navotas City. Metro Manila, Philippines: Navotas Press, 2003.

[21] M. S. Khan, and M. Hasan, Introducing ICT into Teacher-Training Programs: Problems in Bangladesh. Journal of Education and Practice, vol. 4, no. 14, pp. 79-86, 2013.

[22] J. M. R. Asio, "Effect on Performance Review and Faculty Development to Organizational Climate," International Journal of Management, Technology, and Social Sciences, vol. 5, no. 2, pp. 1-10, 2016.

[23] J. M. R. Asio, and E. C. Jimenez, "Professional Development, Organizational Climate, Supervisory Rapport, and Overall Satisfaction of Employees: An Attitudinal Study," International Journal of Scientific Research in Multidisciplinary Studies, vol. 6, no. 4, pp. 3440, 2016. 